\title{
A Conversation with Mililani Trask
}

\author{
Noe Noe Wong-Wilson
}

\begin{abstract}
$M_{i}$ ililani Trask was born into the world of politics and struggle for Native Hawaiian and human rights. Her grandfather, David Trask, was an early member of the Hawai' $i$ Democratic Party, the first Hawaiian sheriff in Honolulu, and a member of the Territorial Legislature for twenty-six years. Her maternal grandmother, Maui-born Iwalani Haia, was one of the first women to organize the Benevolent Societies on Maui and played a key role in the movement to inform Hawaiians of the events surrounding the overthrow of Queen Lili'uokalani in I893. Mililani is the niece of Arthur Trask, well-known orator, lawyer, and politician, and David Trask, Jr, a politician and a key player in labor organizing and collective bargaining for higher wages and better working conditions for public workers. Mililani is descended from the Pi'ilani line of Maui and the Kahakumakaliua line of Kana'i.

Born and raised on O'ahu, the fourth of five children of Bernard and Haunani Trask, Mililani was educated at the Kamehameha Schools. Following her graduation in 1969, she attended the University of Redlands and San Jose State University in California. In 1977, Mililani returned home with a law degree from Santa Clara University.

In I990, Mililani became the first elected kia'aina or governor of $\mathrm{Ka}$ Làhui Hawai $i$, a Hawaiian nation formed in response to the United States' colonial dominance. She was a prominent figure in the Hawaiian political spotlight for over eight years during her leadership of $\mathrm{Ka}$ Làhui Hawai'i. In I993, she served on the prestigious Indigenous Initiative for Peace under the direction of Nobel Laureate Rigoberta Menchu-Tum, the United Nations' Goodwill Ambassador to the UN Decade on Indigenous Peoples. And, in 1995, Mililani became the second vice-chair of the General Assembly of Nations of the Unrepresented Nations and Peoples Orga-
\end{abstract}

The Contemporary Pacific, Volume I7, Number I, I42-156

(C) 2005 by University of Hawai'i Press 
nizations, founded in I99I by his holiness, the Dalai Lama, as an alternative forum to the United Nations. Then, in 1998, Mililani won a coveted seat on the Board of Trustees of the Office of Hawaiian Affairs (OHA), the quasi-governmental organization formed in the 1978 Hawai' $i$ Constitutional Convention. She was elected by the largest number of Hawaiian votes cast in any election since OHA's inception. The Office of Hawaiian Affairs is an organization that has been the object of attack by independence-minded Hawaiian nationalists since its creation. In 2000, after the Rice decision forced the mass resignation of the OHA board members and opened the election process to non-Hawaiians, ${ }^{1}$ Mililani lost her bid for reelection. She is an advocate of peace and has studied and worked with Mother Theresa of Calcutta for seven years. She founded the Native Hawaiian nongovernmental organization Nā Koa Ikaika o Ka Lāhui Hawai $i$, which worked in the international arena on the Draft Declaration for Indigenous Peoples and the World Conference on Racism for the last fifteen years. Today, she has a reputation as an expert on international and human rights law and is a much sought after speaker on native issues. She is currently serving as the Pacific representative on the UN Permanent Forum on Indigenous Issues, based in New York. Mililani and her sister, University of Hawai' $i$ at Mānoa Professor Haunani-Kay Trask, are outspoken critics of the current movement for the establishment of US federal recognition for Native Hawaiians, symbolized by the "Akaka Bill." 2

The original interview took place on 9 July 2003, with follow-up discussions between then and April 2004. Our first meeting took place in Mililani's Hilo office at the Gibson Foundation, a nonprofit organization founded in 1987 to support housing for Native Hawaiians. She focuses on assisting küpuna or elders in the community by providing advice and project support for home construction and repair. This, she feels, is her life's purpose, working selflessly, without pay for her community.

The initial interview lasted for three hours and covered a wide range of topics affecting Native Hawaiians. She possessed a nervous yet vibrant energy, constantly in motion, her pacing accented by her graceful hand gestures. The conversation was intense, as if we could affect the future of generations of Hawaiians by the agreements that were made in our private conversation. At times, the sky opened up and our voices were drowned out by the Kanilehua rains-short bursts of liquid sky that maintain the lush vegetation. Other times, the noise from the low-flying interisland jets overwhelmed us, and the conversation stopped entirely. Once, her voice 
dropped to a whisper as a pedestrian passed by on the sidewalk. I felt like a conspirator, an insider participating in events that would turn the future for our nation. This is her story.

NN: Tell me how you became involved with the sovereignty movement in Hawai'i.

MT: I came home from law school. It was in the late '70s. Alu Like had asked me to work at the 1978 Constitutional Convention ("Con-Con"). 3,4 I was in my last year at law school, and during that time, I attended hearings about Sand Island. 5 There, I heard testimony presented by a group of Wai'anae Hawaiians called Ho'āla Kānāwai, which means "to awaken the law." They were alleging that the Hawaiian people had particular rights that other Native Americans did not, and that Hawaiian rights to land resources were part of the Ceded Lands Trust. ${ }^{6}$ I became interested in what they were doing, and from that time I began to work with them. I wrote a research paper on the Hanapepe, Kaua'i, water case, which raised the issue of Hawaiian entitlements to water. I was working with a Japanese attorney, Mitsuo Uehara. Together we filed an amicus curiae (friend of the court) brief on behalf of the Hawaiian people.

$\mathrm{NN}$ : When did you become involved with the Hawaiian sovereignty movement?

MT: First, I became involved with the Ho'āla Kānāwai group. They were looking at the concept of sovereignty as it could apply to Hawaiians in this modern period, but building on the status of the Hawaiian Kingdom, and even going further back to the time of the monarchy and before western contact. They were trying to look at sovereignty, not only in the US political context, but also the cultural aspects of sovereignty that existed before contact; and what happened during colonization and how our political status had changed. Ho'āla Kānāwai became a statewide nonprofit corporation. They proposed legislation for the creation of a Hawaiian corporation, fashioned after the Alaska Native situation. This was taken into the State Constitutional Convention in 1978.

$\mathrm{NN}$ : Is this when you became involved with the Con-Con?

мт: I was approached by Alu Like to be a researcher for the Hawaiian Affairs Committee of the Con-Con. By that time, the Ho'āla Kānāwai Bill had been in the State of Hawai'i Legislature for two years. They were 
ready to move on their legislation. The idea was that Native Hawaiians could form a corporation, then go to the state for a share of the Native Hawaiian assets. We wanted lands from the Ceded Lands Trust and some money so that the community could address their own needs.

$\mathrm{NN}$ : Was this effort successful?

MT: Unfortunately, the entire effort was co-opted by a group of Hawaiians who were tightly associated with the Democratic Party. Frenchy DeSoto was in charge of the Hawaiian effort at the Con-Con. ${ }^{7}$ Her committee looked at the research and concluded that (I) Hawaiians were not ready for self-governance; (2) the community initiative was a substantial threat, a challenge to the state; and (3) Hawaiians needed a two-step approach. The committee considered the US government's Bureau of Indian Affairs, which has oversight of the Native American Indians. They decided the first step was the creation of a State of Hawai'i-type Bureau of Indian Affairs. They created the Office of Hawaiian Affairs, which emerged after the ' 78 Con-Con. All of the people affiliated with the ConCon plan got Democratic Party support. Henry Peters (a legislator who would become the powerful Speaker of the House of Representatives) and John Waihee (a young lawyer who would become the first Native Hawaiian governor) supported the bill. They said, "Let's create the 'Office of Hawaiian Affairs' and make it a quasi-sovereign entity so it could be part state, part nation. That way we don't have to create a separate nation."

$\mathrm{NN}$ : What was your reaction?

мT: I opposed the committee's decision, left the Con-Con, and continued to work with Ho'āla Kānāwai. It was then that we decided we really needed to work with a larger group—it couldn't be just Ho'āla Kānāwai, a few Hawaiian Homesteaders, but we had to broaden the effort. There were many other organizations looking at this concept of sovereignty: grassroots groups and Hawaiian Civic Clubs were looking at self-governance, Hawaiian Homesteaders were discussing sovereignty, ${ }^{8}$ Native Americans were coming to Hawai'i to talk about sovereignty, other Hawaiians were going to the United Nations. We decided that we would have a hālāwai, a gathering, and it was decided that a new group should form so that Ho'āla Kānāwai could remain intact.

$\mathrm{NN}$ : Who else was involved with this movement? 
мт: The president of the Ho'āla Kānāwai was Blackie Hoohuli. Aunty Apolonia Day from Maui, Aunty Marie from Wai'anae, Aunty Pele Hānoa, and others were involved in the Ho'āla Kānāwai movement. A new group was formed called the Native Hawaiian Land Trust Task Force. It was headed by kūpuna from each island. One of its central goals was accountability, because we realized that the Ceded Lands Trust assets were being encumbered, sold, and developed before Hawaiians could get the sovereignty question addressed.

NN: What action did the Native Hawaiian Land Trust Task Force take?

мт: The task force took its legislative initiative to the US Congress, which then called for an investigation of the Hawaiian Home Lands program. A Federal/State Task Force on Hawaiian Home Lands was set up in 1982. The Federal/State Task Force continued to bring together all kinds of Hawaiian groups, not really sovereignty groups, but grassroots groups looking at sovereignty. Many kūpuna from the grassroots communities were involved. After a number of years, the report on the Hawaiian Home Lands situation was published. It was worse than we had thought. Much of the land was being used for public purposes. We realized that the Hawaiian Home Lands comprised nearly 200,000 acres of rocks, unsuitable for agriculture, and, to make matters worse, while we were trying to focus on the homestead issue, we had not been paying attention to the larger land issue-the Ceded Lands Trust. So, we decided we would call for a big, statewide hālāwai. We decided that the time had come to call for a constitutional convention.

NN: Did Hawaiians respond?

мт: The response was overwhelming. Hawaiians came from all over. The gathering occurred at Mālia Puka o Kalani church in Keaukaha in 1987. The rules were simple-come, regardless of age, or what group you were with, or if you were by yourself, just come. We really did it as a grassroots effort. At the end of the constitutional convention, we had to name the nation and the nation's name was Ka Lāhui Hawai'i; that is how it was born. It was an effort of the Native Hawaiian Land Trust Task Force.

NN: Tell me more about Ka Lāhui Hawai'i.

мт: Hawaiians drafted the first constitution; every few years there would be a convention to consider constitutional amendments. The constitution structured the government. We dealt with very basic concepts. What type 
of structure would be culturally appropriate for Hawaiians and still allow us to interface with the United States and other native nations? The idea of a bicameral legislature didn't make sense. When Hawaiians meet, everyone sits in one circle. That concept emerged as a unicameral government. For Hawaiians, the American notion of one-man, one-vote didn't work. It was culturally inappropriate. In Hawai' $i$, governance was never one-man, one-vote. It was the Ali'i or chiefs of the islands who had certain powers. But, in this modern day and age, you cannot govern by bloodline alone, because you have Hawaiians with bloodlines from Kaua'i, now living on O'ahu, for instance. Should these people decide what's going to happen on Kaua' $i$ when they don't even live there? But bloodlines were important and needed to be included in some appropriate way. The reason why Ka Lāhui Hawai'i has such a good constitution is because the process was created and implemented by Hawaiians to address their own concerns and rights. In order for a constitution to reflect the people's desires and political will, it must be written by the broadest and most representative group of Hawai'i's peoples. Representation based on "population" favors urban centers and westernized values. When representation is based on "community," the real value of Hawaiian cultural enclaves (such as the fishing villages of Miloli'i and Kalāpana or the taro growers of Waipi‘o) will be included in the outcome. Ka Làhui Hawai'i processes were created by Hawaiians to enhance their right of self-determination. Its constitution addresses marine resources and cultural, spiritual, and traditional practices, because Ka Lāhui Hawai'i processes ensured that Hawai'i fishermen, planters, spiritual leaders, and cultural practitioners were delegates to the constitutional process. Self-determination is not only a human right but also a process for empowerment, nation building, and conflict resolution.

NN: Is Ka Lāhui a democratic nation?

мT: Yes, we thought that democracy was also an important concept. So, Hawaiians put the purest example of Hawaiian self-determination and self-governance into Ka Lāhui Hawai'i's constitution. This is why, for instance, in Ka Lāhui, you have a unicameral, collective decision-making process and not a one-man-one-vote system. In Ka Lāhui Hawai'i, power is equalized. Each island-O'ahu, Kaua'i, Ni'ihau, Maui, Moloka'i, Lāna'i and Hawai'i Island-has eight votes. Regardless of the population, each island should have a fair say. We also looked at conflict resolution. In traditional times we practiced ho'oponopono, a method of conflict resolution. Some Hawaiians said, "We want to have a judge." So when we 
drafted the constitution, we included elected judges, or, if citizens prefer, they can go to the Kūpuna (Elders) Council for Ho'oponopono. You cannot choose both, but you have a choice, either the traditional or the modern. We considered issues such as burial rights, fishing, land rights, how to protect our culture. That's why Ka Lähui Hawai'i has the Ali'i branch of government. The Ali'i council is Ali'i blood, and they look after culture and protocol. It's not for the elected government to try to implement cultural protocol, it's the job of those who have been the cultural keepers of protocol. These kinds of things were worked out in the constitution so that the government structures would be reflections of culture, and would protect and address tradition.

NN: How many citizens belong to Ka Lāhui Hawai'i?

MT: We eventually went from a handful, about 250 , to over 20,000 , with adults and children in Hawai' $i$ and also on the continent. We struggled with issues like blood quantum and incorporation of Hawaiian cultural as well as western ideas. Many different sovereignty groups were emerging at the same time. Ka Làhui's first step was to form a nation within this political environment (nation-within-nation US structure), while developing an international strategy. We knew there were limitations under the US system that could never be addressed under US domestic law. Because of our previous history with the United Nations, we decided we had to go to the international arena.

NN: What is the relationship between Ka Lăhui Hawai'i and the United Nations?

MT: A lot of people looked at Ka Lāhui and said we were selling out, we wanted to be under the US system. This was not quite accurate because what we were saying was that the first priority was not a political relationship with the United States. The first priority was to protect the land and protect the people; education, health, and cultural preservation. The first priority was to create a Hawaiian nation to facilitate self-determination at home. The political strategy for dealing with the United States was the second priority. Under the United States, indigenous people can achieve only limited rights, but we could obtain land for our people's needs. And, we could at least get a share of our revenues to develop health, education, and culture. Those were Ka Lāhui's priorities for the eight years I served as kia'aina of the nation. 
$\mathrm{NN}$ : Was there widespread support for those priorities?

мT: There was consensus but not complete unity. The criticism that we don't march to the beat of a single drum, that we don't stand in unity, is out of political necessity. That criticism comes with a western bias and is imposed on native people. We Hawaiians were never unified, we always had different kuleana or responsibilities until the time of Kamehameha. Kamehameha unified the islands, but how? It wasn't through native practice-ho'oponopono-but with the gun of the white man and through war. What eventually became established was not just simply Hawaiian, but rather, a monarchial structure. I don't blame Kamehameha, and as far as I'm concerned, I will always honor the Kamehameha monarchs. Our people went from a traditional lifestyle to occupation by outsiders, and haoles (foreigners) taking over, in one generation. Kamehameha looked around; he was concerned about the survival of our peoples, and he saw a monarchial structure in Europe. Hawaiians had many treaties with Europe. Hawaiians knew that change was coming and they did the best they could. It's pointless to blame Hawaiians who lived during the monarchy. If we had lived in their times what would we have done? I don't know if we would have done any better.

Nevertheless, we were trying to address sovereignty but the system created the Office of Hawaiian Affairs. OHA was moving ahead with their state initiative, and we had the political realities of the state Democratic Party, which controlled our assets. The party is heavily dominated by Japanese Americans and they want to remain in power and in control of the state's land trusts. That's where we are today. We are dealing with the same old structure. Hawai' $i$ is the only state in the union that has never really had a two-party system. So, the checks and balances of the US twoparty system-Democrat and Republican-are meaningless to us, meaningless! Republicans are in power now because Democratic voters are sick of what the Democratic Party has become, not because the people are all Republicans. This is how my involvement with Ka Lāhui developed. When I stepped out of office in I998 it was because I had served two terms as kia'äina and according to the Nation's constitution, I couldn't run again for that position.

$\mathrm{NN}$ : One of the most important issues facing Hawaiians today is whether or not to support the move for federal recognition. Can you share your thoughts on the "Akaka Bill"? 
мт: We need to go back to the first draft of the "Akaka Bill” and determine its purpose. The purpose was to begin to address reconciliation and the "Apology Resolution" and to restore to the native people the right of self-determination. ${ }^{9}$ What is the purpose of the current "Akaka Bill," Senate bill 344? The purpose of the current "Akaka Bill" is to create a process for federal recognition and to protect the pork-barrel funding for a huge service agency structure.

As a by-product of this effort, you have to create a nation, because you can't "recognize" a nation that doesn't exist. The purpose of this bill is not to create a Hawaiian nation, but to create a process for "federal recognition." We had sovereignty before the overthrow. The Apology Resolution says that as a result of the overthrow, international law was violated, Hawaiians lost their right to sovereignty, Hawaiians lost their right to selfdetermination. However, Hawaiians never relinquished their claim to lands or their rights to a plebiscite or referendum. Our government was overthrown by armed US military forces.

What is the Apology Resolution talking about? It is talking about our right as an independent native people to self-determination under international law. Under international law, it is the right of all peoples to determine their own political status, and by virtue of that right, to freely pursue their cultural, social, and economic development. The right of economic development comes from the right to self-determination. The right for cultural development, preservation, and social development evolves from the right of self-determination, which begins with the right to determine our own political status. If this bill is written properly, we could get out of a wardship relationship with the US and begin our road back to nationhood. This is based on the definition of human rights under international law.

NN: So, why is the "Akaka Bill" so controversial among Hawaiians?

MT: In the current "Akaka Bill," strangely, there begins to be manipulation of the concept and right to self-determination. The bill says that Native Hawaiians express their right to "self-determination" by getting "government services." For example, health funds go to Papa Ola Lōkahi; education monies go to the Center for Hawaiian Studies; language immersion funds go to 'Aha Pūnana Leo; employment training monies go to Alu Like, Inc; economic development goes to Alu Like, Inc, and the Council for Native Hawaiian Advancement (CNHA); ${ }^{10}$ children's services go to the Queen Lili'uokalani Trust; the list is exhaustive. These Hawai- 
ians express their right of self-determination by securing a place on the pork-barrel line. Today, all of these nonprofits control the Council for Native Hawaiian Advancement, which controls and receives over 70 million dollars a year for Hawaiians. They are also controlling the process on the "Akaka Bill."

The bill says that Hawaiians have the right to self-determination, but it defines self-determination as dependency. The US policy limits indigenous rights to internal control over certain matters. Indian nations, at best, are autonomous. There are overlapping state, federal, and Indian jurisdictions. There are some things Indians don't have a say about, like military bases. That would be very convenient here in Hawai' $i$, because so much of the ceded lands are militarized by the United States. With regard to Hawaiian Home Lands, you have to go to the US Congress to make any changes. So, in the current "Akaka Bill," you can see US policy strongly emerging. In addition to the policy issues, there is a redefining of the concept of self-determination. Now, who drafted this? Not Hawaiians.

Many Hawaiians are confused because they don't understand the process and there has been little education. Hawaiians have not seen or testified on the last four versions of the "Akaka Bill." Some Hawaiians understand full well what is happening, but they want the kālā, the money. They want to advance their careers and they are getting older. I have great disdain for such people. These are the kinds of questions to ask when considering this bill. Did Hawaiians write it? No. Did Hawaiians testify? No. And they made damn sure there was no opportunity for anybody to make the Congressional Record. Who supports the Hawaiian bill, and who opposes it? It's not just white racists who oppose it; there are a lot of people who can't support it because they don't understand it. There are a lot of people like myself who can't really support the bill because it offends the very principles of transparency and inclusiveness. For god's sake, if you don't want to have an official congressional hearing here, then launch an educational effort and have the people write testimony and send it to Congress. But the few controlling the process have insured that only CNHA, the state governor, the state OHA and the state Department of Hawaiian Home Lands are involved.

In the international arena, the world is having elections. In the I950s, there were many dictators. There were no elections. Nowadays, all over the world, we have democratic elections. This is why there are UN observers for elections, because you don't want power to manipulate the election process. 
Senator Inouye says he has had hearings in Hawai'i, and that Hawaiians supported the bill, but it's not the same bill it was years ago when we were dealing with the first draft written by Hawaiians. The truth is that the reason the support for the original bill was so great was because Hawaiians wrote the first bill and were allowed to testify at hearings in Hawai'i. In Hawai'i, Senator Dan Inouye made a list of who could testify, and not more than four groups in opposition were allowed to testify. I found this out quite a bit later from Aunty Gladys Brandt. I didn't know that this happened.

NN: Did you testify on the bill?

мT: Yes, but the way I got to testify was not by invitation from Inouye. The way I got to testify was I wrote to a senator who came down to Hawai'i years ago. He later ran for vice president, a Republican from Arizona, Senator John McCain. I wrote to Senator John McCain. I met him on Moloka'i. He and his wife came, we had a meeting over there, and she was just shocked to find a small group of us from Ka Lāhui holding up signs. The hearing on Moloka'i excluded Hawaiian people. After that, I always went to see Senator McCain. He told me, "If I ever get the Chair, we'll move something for Hawaiians."

When the hearing happened on the first bill, Senator Inouye's clerk, Pat Zell, told me that I couldn't testify. I wrote to Senator McCain and his clerk called me and said, "Senator McCain is taking a position that you will testify and a memo has gone out requesting that you be allowed to testify." That's how I got to speak. I didn't know that there were other Hawaiians who wanted to testify as well. Aunty Gladys Brandt told me that when she received the notice to prepare testimony she also learned who was on the list. All the other hearings that they had on the neighbor islands in Hawai'i didn't count. Senator Inouye said the only "official" one was over there in Washington DC, and the excuse was that Senator Dan Akaka was having a back operation, so neighbor island hearings were not "official."

Then the second version of the "Akaka Bill" came out. No hearings were held for the Congressional Record in Hawai'i on the second or subsequent versions of the bill. This second "Akaka Bill" was different from the first bill. They are all called the "Akaka Bill." So, they are very craftily manipulating the Congressional Record. The only people who went up to testify were the state OHA trustees, the state governor, and the state Department of Hawaiian Home Lands. Nobody who opposed had a 
chance to participate directly. Nobody could get funding to travel to Washington DC.

$\mathrm{NN}$ : Can you discuss the current version of the bill, s 344 ?

мт: We have to ask ourselves the question, "Can we salvage anything?" What we have now in the bill is that the adult Hawaiians will have an election for an interim government, and the adult Hawaiians will then certify the list of names, or roll, that the Secretary of Interior will create. The federal census says there are about 400,000 Hawaiians in the United States. We know that of the nearly 240,000 Hawaiians who live in Hawai' $i$, 70 percent are age eighteen or older. If 70 percent of the Hawaiians who reside on the continent are adults, we have potentially 280,000 Hawaiians scattered across the archipelago and all over the United States. How the hell are 280,000 people going to get organized and put together an election? They need to raise the funds, coordinate the election, and how are they going to certify the roll? How can 280,000 individuals living thousands of miles apart implement the bill? Well, those with the money and those with the organizational mechanisms who are working with Washington DC will carry the ball by default. Who will that be? OHA and CNHA.

When you look at what's actually happening now, the bill is poorly written. Who's making the decisions? Who's going to certify the roll? The bill says the adult Hawaiians will. Who's going to do the elections? The bill says the adult Hawaiians will.

The nation is not 280,000 individual adult Hawaiians. How can they establish an enrollment process? The efforts of OHA and CNHA to enroll Hawaiians are limited to Hawaiian Home Lands, service agency groups, and the US continent. And you know, there are so many definitions of Hawaiians in this bill, you don't know if you are "native," "aboriginal," or "indigenous." How many definitions do we need? OHA and CNHA claim they want to start out with an "inclusive" definition, but by the time we get to the roll, we have a definition of Native Hawaiian that is limited to those who qualify for Hawaiian Home Lands.

"Native Hawaiian" is defined in three parts. The general definition is: Native Hawaiians are the indigenous, native people, direct lineal descendants of those who resided here in 1893 , who exercised sovereignty, and whose ancestors were eligible for Hawaiian Home Lands in I92I. In order to meet this definition, the only people automatically included were those who were on the state's Hawaiian Home Lands list. Even the Wall 
Street Journal has run articles on how the Hawaiian Home Lands were awarded to those with political pull. The bill says that only these Hawaiians who can prove that their ancestors occupied and exercised sovereignty in Hawai'i prior to I 893 can participate. It is unclear how Hawaiians are expected to prove this. It is doubtful that any Hawaiian has an election ballot stub from their great-grandfather.

Do you know the story of our Royal Hawaiian Band? There was a famous Royal Hawaiian Band. And then, in I893, suddenly, the Royal Hawaiian Band was no more. Why? Because the members of the Royal Hawaiian Band would not sign the oath of loyalty, and because they never signed, the Royal Hawaiian Band was disbanded; they wouldn't swear an oath of loyalty against the queen in support of the US provisional government. So the oath of loyalty was signed by haoles and traitors to the queen. It is doubtful that any Hawaiian today can prove they exercised sovereignty by supporting the overthrow! How many Hawaiians do you think will do research to come up with their "proof"? How many Hawaiians do you think can do this?

$\mathrm{NN}$ : What can we do as individual Hawaiians to change this process?

мт: What strategy do we take as Hawaiians? Do we boycott it? Do we participate and try to counter-organize? We could make our own roll. We could run independent candidates. We could run Kingdom candidates. We could get a hundred Hawaiians to sign up and then we could write a constitution. I know, because I wrote a constitution for Ka Lāhui Hawai' $i$, and we went through several constitutional conventions. Ka Lāhui has a damn good constitution, but is anybody going to be there to talk about it? A boycott is just what the United States wants. They want the leaders who are on the pork-barrel line to be the leaders of this nation. Do we go along with it? Are we getting co-opted by participating in the process that we know ourselves has already excluded our people? How the hell can we participate in the damn thing? How can we not participate in it, knowing where it is going, looking at the poverty of our people? What are we supposed to do? Just in the last two months, several groups have been involved in this discussion. We haven't made the Congressional Record about where our people are on this issue. We haven't had the chance to testify on these bills. Just in the last few months, several groups have been involved in this discussion.

When OHA and CNHA announced they were enrolling people into the "Akaka" nation on I7 January 2004, many Hawai'i leaders moved to 
oppose the effort. A working group on self-determination was formed to counter the OHA/CNHA effort with a proposal for a community-based coalition to support sovereignty rather than the flawed "Akaka Bill." On 28 February 2004, at a meeting between the OHA-appointed CNHA Advisory Council and the Native Hawaiian Working Group on Self-Determination, Hawaiian leaders rejected the advisory body and supported the creation of a community-based coalition. The OHA board, however, continues to support exclusivity and has spent an estimated three million dollars lobbying for the measure. In March 2004, OHA began a series of "Hawaiian Parties" on the US continent, featuring free food and Hawaiian music, for anyone willing to enroll in the "Akaka" nation.

Postscript: The "Akaka Bill" continues to languish in the US Senate. Another version of $\mathrm{s} 344$ was drafted for introduction to the US Congress, but as of July 2004, the bill had not been reintroduced for a floor vote. Supporters are concerned that the bill is being purposely stalled by opponents who have convinced some Senators to withhold their support. [For more on the "Akaka Bill," see the article by J Kēhaulani Kauanui, this issue, pages I-27.]

\section{Notes}

I The Rice case is a lawsuit, which prevailed in the US Supreme Court, claiming that the Hawaiians-only voting policy for trustees of the Office of Hawaiian Affairs constituted racial discrimination. In 2000, the OHA trustees chose to resign en masse. State Governor Benjamin Cayetano named interim trustees, including the first non-Hawaiian on the board. Mililani Trask lost her subsequent bid to regain a seat on the board.

2 The "Akaka Bill" refers to federal legislation that proposes to provide federal recognition for Native Hawaiians. Several versions of the bill have been circulated in the community for comment. A current version of s 344 proposes to establish US federal recognition for Native Hawaiians and to set up a process for creating a Native Hawaiian governing entity.

3 Alu Like, Inc, is a Native Hawaiian organization that provides health and social support services to Native Hawaiian communities.

4 In 1978, the Hawai'i State Legislature convened a constitutional convention. It was most noted for creating a series of legislative bills that established Native Hawaiian programs and rights, including the Office of Hawaiian Affairs. The Con-Con has not been convened since. 
5 The State of Hawaici claimed ownership of Sand Island, a ten-acre dredged landfill used as a seaplane runway during World War II. In 1979, over ıoo Hawaiian families who maintained a fishing lifestyle there were evicted from their homes by the state, to make way for development. This conflict brought the issue of the state's abuse of the Ceded Lands Trust to the forefront of public attention.

6 The term "ceded lands" refers to Crown lands that were claimed by the Provisional Government after the overthrow of the Kingdom of Hawai' $i$. These lands were subsequently transferred to the Republic of Hawai'i and eventually were incorporated into the State of Hawai'i under the Statehood Act in 1959. These lands, which consist of approximately two million acres, are supposed to be held in trust for the Native Hawaiian people and are not supposed to be sold, traded, or otherwise disposed of by the State of Hawai' $i$. Many Native Hawaiian groups have criticized the State of Hawai'i for breaching the trust by illegally selling and transferring these assets. Twenty percent of the revenues from ceded lands are supposed to be paid to the Office of Hawaiian Affairs; however, the state has failed to account for all of the assets and revenues from the Ceded Lands Trust and is several million dollars in arrears. The issue has not been reconciled.

7 Frenchy DeSoto was instrumental in forming the Office of Hawaiian Affairs and served as trustee for twenty years, since its beginnings. She resigned from office in 2000 along with all the other trustees, in response to the federal Supreme Court determination that non-Hawaiians should be allowed to vote and run in the онA trustee elections.

8 In I92I, the US Congress approved the Hawaiian Homes Commission Act of 1920 , which set aside approximately 200,000 acres of land for the rehabilitation of native Hawaiians. Homesteaders are required to prove that they have a minimum of 50 percent native Hawaiian blood.

9 The 1993 "Apology Resolution" (Public Law I03-I 50, signed by President Bill Clinton) in part recognizes that "the indigenous Hawaiian people never directly relinquished their claims to their inherent sovereignty as a people or over their national lands to the United States, either through their monarchy or through a plebiscite or referendum" and "apologizes to Native Hawaiians on behalf of the people of the United States for the overthrow of the Kingdom of Hawaii on January I7, I893 with the participation of agents and citizens of the United States, and the deprivation of the rights of Native Hawaiians to selfdetermination." The resolution calls for the reconciliation process to begin.

Io The Council for Native Hawaiian Advancement was formed in May 200 I to promote the advancement of Native Hawaiians through empowerment and informational initiatives. 